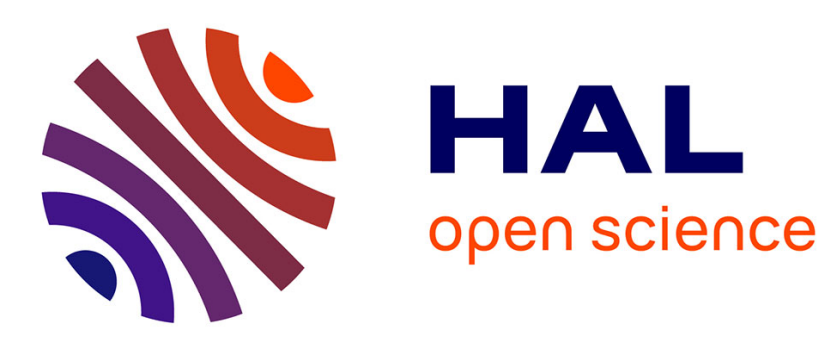

\title{
Towards a Re-Definition of Technology Management
} Jean-Jacques Chanaron, Thierry Grange

\section{To cite this version:}

Jean-Jacques Chanaron, Thierry Grange. Towards a Re-Definition of Technology Management. The 3rd IEEE International Conference on Management Innovation and Technology, Jun 2006, Singapore, Indonesia. halshs-00137074

\section{HAL Id: halshs-00137074 https://shs.hal.science/halshs-00137074}

Submitted on 16 Mar 2007

HAL is a multi-disciplinary open access archive for the deposit and dissemination of scientific research documents, whether they are published or not. The documents may come from teaching and research institutions in France or abroad, or from public or private research centers.
L'archive ouverte pluridisciplinaire HAL, est destinée au dépôt et à la diffusion de documents scientifiques de niveau recherche, publiés ou non, émanant des établissements d'enseignement et de recherche français ou étrangers, des laboratoires publics ou privés. 


\title{
Towards a Re-definition of Technology Management
}

\author{
J-J. CHANARON. \& T. GRANGE \\ CNRS \& Grenoble Ecole de Management \\ BP 127 \\ 38003 Grenoble Cedex 01 France
}

\begin{abstract}
The paper is proposing an historical approach of the definition and constitution of technology management as a discipline leading to a re-visited approach more in line with contemporary issues and problems facing businesses. It is suggested to expand its scope to the strategic management of technology and innovation.
\end{abstract}

\section{INTRODUCTION}

The question of whether it is relevant to maintain or even develop academic research and specific education programs in technological management clearly fuels current discussions on the role and the position of scientific and technical research in the European Community as well as the role of innovation in the wealth of its economy. As Le Boucher [1] puts it so nicely about France "its industry is outdated and its research efforts are insufficient and inconclusive... Its competitiveness is threatened by the United States on the one hand and by China on the other".

This really set the proverbial cat among the pigeons in ultraliberal ranks of "la pensée unique": public backing of technological innovation in the manufacturing sector was to be one of the motors of the rebirth hailed by many official reports released at European and national levels and the core objective of the European industrial policy

The central role of technological innovation in economic growth has of course been acknowledged by economists of the Schumpeterian school of thought for quite some time. But, so far, it has neither been integrated, nor a fortiori implemented in terms of corporate strategy by major industrial groups, members of the scientific and technical community, or a fortiori by the political classes and the administration. Today, it is paramount to bear in mind that, within the European Union, a general consensus has been reached amidst the economic community, relayed by actors of the scientific and technical system, and carried or if not shared by politicians, concerning the central role of innovation in the defense and reinforcement of corporate competitiveness. Some even go so far as to consider technological innovation as the sole life-line of companies in industrialized countries where globalization is increasing and worldwide competition is heightened to an extreme. A similar movement can be observed in the US, Japan and Korea as well as India and China and many others. Members of the scientific and industrial community place the capacity to innovate, in the foreground of research and development, as the key to the competitiveness of nations and companies.
This article is not a research-based investigation but rather a reflection on the disciplinary characteristics of an emerging management field which sets science, technology and innovation at the core of its concerns. It aims at putting actual definition within an historical perspective and drawing a set of priorities for its research agenda.

\section{TOWARDS A DEFINITION OF TECHNOLOGICAL} MANAGEMENT

\section{Shortcomings of literature}

It is symptomatic to observe that academic literature endeavoring to build an epistemology of technological management is scarce, despite the abundance of scientific publications claiming to do just that.

Since the founding documents of the IAMOT, the International Association for Management of Technology, adapted from the reflections of an ad hoc committee of the National Research Council in 1987 [2] and the American National Science Foundation [3], and a few exploratory articles by Barrand \& Jolly [4], Chanaron \& Jolly [5]; Chanaron, Jolly \& Soderquist [6], a literature search provides very few references, most of which are limited and devote only a few lines to the matter. Most of the actors bidding claim to management of technology carefully sidestep the precarious exercise of proffering an academic definition. Christensen [7] considers that the management of technology implies its diversification and integration. Even textbooks targeting engineering and management school students do not attempt to contribute to what nonetheless must be clarified [8]. Chanaron \& Jolly [5] did propose a clarification (figure 1).

This "academic" perspective has the merit of federating nearly all of the work undertaken by researchers bidding claim to technological management since the mid-1980s. Although still valid, it would obviously benefit from added reflection, especially in terms of its operational implementation.

\section{A contemporary vision}

Beyond these sterile semantic quarrels, a «modern» or contemporary vision of technological management could be the following: 


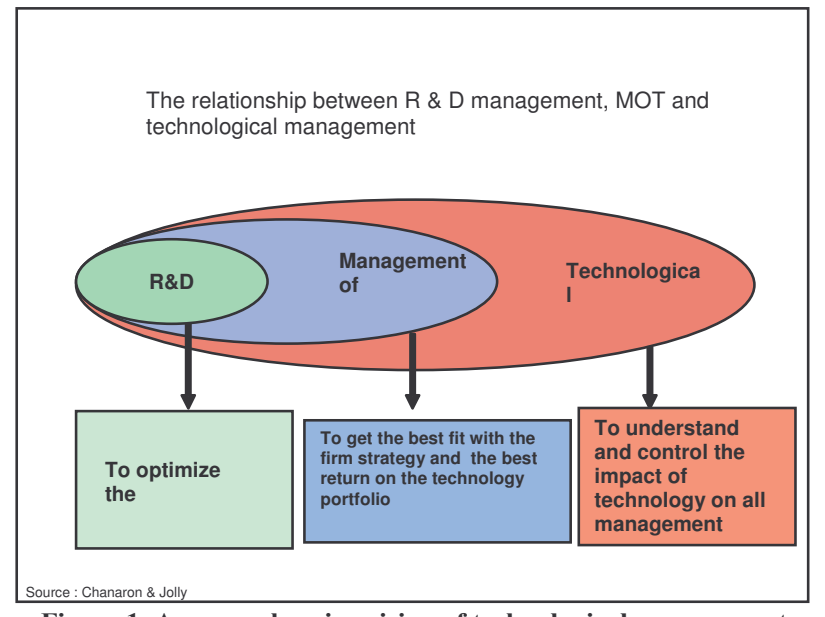

Figure 1. A comprehensive vision of technological management

- At a macro-economic level (region, nation, etc.), it involves mobilizing resources to create and implement individual and collective knowledge and know-how on markets. Request for such research at macro-level is indeed reinforced by the rising concerns regarding the relationships between science, technology and society from a positivist vision of innovation as a source of growth towards a more reflective approach of innovation as a foundation for sustainable development.

- At a micro-economic level, i.e. the company, it implies managing what adds value to products and services on the market to create wealth; it is therefore managing the application of knowledge and know-how in order to generate value.

Technological management is the management of innovation, whether it be a product, a process or an organization, from its conception to its diffusion, and therefore to its implementation within the company, including the consequences, advantages and disadvantages for all of the variables and actors involved in running the company. Innovation is seen a any change produced by technology in an organization towards the satisfaction of its economic goals, i.e. providing an economic advantage in fine as stated by Chanaron [9]. Technological management is then the management of change, i.e. the Management of technology. But it also involves management by or through technology, or, in other words, how technology is used to run the company, then the management of the appropriation of technology by the organization. It is a set of tools that creates value by generating new markets and opportunities and/or by reducing production and transaction costs

\section{Science or art?}

One reason behind the epistemological weaknesses that characterize management of technology comes from the fact that it never laid claim to being a scientific discipline, but only an " art» serving organizations and their managers. It cannot therefore be qualified as knowledge relating to phenomena that abide by rules that have been tested by experimental procedures, but, at best, a localized and dated synthesis of best practices, i.e. of the most efficient applications in terms of satisfying the objectives of the organization that implements them. Yet, academic specialists refer either implicitly or explicitly to a specific field of management sciences. Burgelman, Christensen \& Wheelwright [8] assert that technology and innovation should be managed, meaning as scientifically as possible, since they claim to synthesize the specific concepts, tools, methods and processes of the strategic management of technology and innovation.

When Scabrough \& Swan [10] attempt to define knowledge management, they are inclined to favor a notion of art that is essentially fashioned by trend: a vague set of ideas, tools and practices focusing on the communication and exploitation of knowledge within the organization. In actual fact, like most functional disciplines in management sciences, technological management is neither a science, in the sense of « core » discipline, i.e. giving rise to paradigms and universal laws, nor an art, in the sense of fine arts, but a science of action as pointed out by Hatchuel [11]. The knowledge produced by research in management science could answer the decisional and analytical needs of companies, an «actionable " knowledge, such as in medicine where a diagnosis precedes therapy. Indeed management sciences follow a clinical logic and frequently implement pluri-disciplinary knowledge.

3. THE PRIORITY ISSUES ADDRESSED BY THE STRATEGIC MANAGEMENT OF TECHNOLOGY AND INNOVATION

Assuming that management of technology emerged in the eighties, the main themes or issues of the discipline have naturally evolved over the years in accordance with changes in techniques and organizations.

\section{The founding-fathers}

In 1990, at the second international conference of the IAMOT, Khalil and Bayraktar [3] published eight fundamental questions to be addressed by management of technology:

1. How should technology be integrated into the objectives of corporate strategy?

2. How can technologies be released and accessed more quickly and efficiently?

3. How can technology be assessed more efficiently?

4. How can the transfer of technology be optimized?

5. How does one reduce the development time of a new product, process or organization?

6. How should major, interdisciplinary and interorganizational projects or complex systems be managed?

7. How should the internal usage of technology within the organization be managed? 
8. How can the efficiency of technical personnel be improved?

In 1999, the results of a DELPHI survey, conducted in the mid-eighties with 63 academics and industrials from 17 countries (table 1), clearly pinpointed strategic planning of technological products as the top priority of technological management [12], i.e. the management of innovations, way beyond purely methodological aspects.

Table 1. Key MOT issues

\begin{tabular}{|c|l|c|}
\hline$\#$ & Theme & \\
\hline 1 & Strategic planning of technological product & 8,3 \\
\hline 2 & Project selection methods and criteria & 7,3 \\
\hline 3 & Methods and tools for organizational learning & 7,3 \\
\hline 4 & Identifying and developing key competences & 7.2 \\
\hline 5 & Reducing the duration of the development life cycle & 7,1 \\
\hline 6 & Creating an ad hoc culture & 7,1 \\
\hline 7 & Coordinating and managing new product development teams & 7,1 \\
\hline 8 & Analyzing and understanding technological trends and shifts & 7,0 \\
\hline 9 & Involvement of marketing teams & 7,0 \\
\hline
\end{tabular}

\section{A historical perspective}

One can take also a dynamic approach to the issues of technological management and record the evolution in time and space of corporate rationalities and objectives (figures 2 and 3 ).

Phase 1 - 1982-1992 - corresponds to market globalization and demands the optimization of the whole production process, from research \& development to commercialization, even to recycling, including procurement and logistics. The managerial watchword is optimization. The main principle of management is indeed to deliver to the right place, at the right price and respect an agreed deadline. Technological offers are profuse in this first stage: the purpose of technological management is therefore to select and manage choice.

Figure 2. The three phases of technological management

\begin{tabular}{|c|c|c|c|}
\hline & Objective(s) & Variable(s)-key(s) & Technologie(s) \\
\hline $1982-1992$ & $\begin{array}{l}\text { Modernize the } \\
\text { production tool }\end{array}$ & $\begin{array}{l}\text { Quality } \\
\text { Productivity }\end{array}$ & $\begin{array}{l}\text { Robotics } \\
\text { Productics }\end{array}$ \\
\hline $1992-2002$ & $\begin{array}{l}\text { Deploy and integrate } \\
\text { Information systems }\end{array}$ & $\begin{array}{l}\text { Costs } \\
\text { Quality }\end{array}$ & $\begin{array}{l}\text { Internet } \\
\text { E-business }\end{array}$ \\
\hline 2002-2012 & $\begin{array}{l}\text { Innovate and optimize } \\
\text { the life cycle }\end{array}$ & Change turnover & $\begin{array}{l}\text { Nanotechnologies } \\
\text { Natural sciences }\end{array}$ \\
\hline
\end{tabular}

The second phase - 1992-2002 - witnesses heightened competition, still in the context of growing market globalization, but now associated with globalized production, technologies and financial resources. The general rule of thumb is an all-out race towards cost reduction, which includes implementing ad hoc processes and organizations. The managerial keywords have now become «re-engineering» and efficiency. The issue is now to refocus on key competencies, and outsource what can't be done or what could be done better. The core principle of management becomes control, and therefore the availability of pilot information. Technologies are still over abundant, but the central problem of technological management is their deployment within the economic system.

Figure 3. Predominant purposes, methods and and principles of the three phases of technological management

\begin{tabular}{|c|c|c|c|}
\hline & Purpose & $\begin{array}{l}\text { Predominant } \\
\text { method(s)) }\end{array}$ & $\begin{array}{l}\text { Management } \\
\text { principle }\end{array}$ \\
\hline 1982-1992 & $\begin{array}{c}\text { The firm as a continous } \\
\text { process }\end{array}$ & Optimisation & $\begin{array}{l}\text { "Delivery " } \\
\text { kanban }\end{array}$ \\
\hline 1992-2002 & $\begin{array}{l}\text { The firm as a } \\
\text { nexus of projects }\end{array}$ & $\begin{array}{l}\text { Re-engineering } \\
\text { Outsourcing }\end{array}$ & $\begin{array}{l}\text { Control } \\
\text { Information } \\
\text { system }\end{array}$ \\
\hline 2002-2012 & $\begin{array}{l}\text { The agile, transformable } \\
\text { and } \\
\text { ductile firm }\end{array}$ & $\begin{array}{l}\text { Anticipation } \\
\text { Organizational } \\
\text { Life cycle } \\
\text { management }\end{array}$ & $\begin{array}{l}\text { Lean } \\
\text { management }\end{array}$ \\
\hline
\end{tabular}

The third phase, since 2002, puts winning competitive advantage at the heart of corporate strategy. The central management principal becomes « lean » management from design to commercialization and for all factors of production, physical as well as intellectual assets and labor. Cost reduction returns as a determining priority. It implies building flexible, agile and ductile organizations that can be remodeled at will to improve their capacity to adapt to markets, innovate and appropriate niches. It therefore makes sense to develop the capacity to anticipate consumer and user expectations, i.e. business opportunities, and as quickly as possible. The central principle of management is the rate of change and the capacity to renew offers of technology.

Which fields of investigation?

The strategic management of innovations and technology covers a vast area of research, reflection and managerial practices:

- Strategic reflection on the role of technology in attaining the objectives of corporate strategy: What role and what priority should be given to innovation and technology? What are the technologies of the future? What are the mainstream trends liable to impact on the emergence and rate of diffusion? Which key technological competences should be maintained, developed, abandoned and at what rate? What are the markets of the future?

- Strategic reflection on internal organization and industrial relations with corporate partners: Undertake, 
acquire, or delegate technological development? Acquire, merge or develop technological alliances? Which human and financial resources? Which systems should be used to assess the performances of the organization and piloting?

- Operational management of the innovation process: Management of research \& development and design; Management of knowledge and know-how; Management of the specific competencies of technical personnel; Management of research-developmentdesign personnel; Management of technological acquisitions, partnerships, alliances and contracts; Management of budgets allocated to research, technological scanning and innovation marketing; Management of market release.

- Management of the «technological» value chain and the innovation process: Industrial management of scientific and technical projects; Management of interfaces between research \& industry; Management of budget allocations to research, technological scanning and innovation marketing; Management of the localization of knowledge production activities, especially poles of excellence; Management of market release.

- Management of innovative product marketing: Understanding the determinants of new product performance; Strategies for managing competitive reactions; Management and composition of new product development teams; Methods for forecasting sales of new products; Methods for setting prices of innovative products; Management of the life of new products, including the launch agenda; Management of communication, especially the « pre-announcement »

- Reflections on the specificities of SMEs in their relationship with technology and innovation:

Even though SMEs often face similar problems to those encountered by major groups in terms of the management of technology and innovation, it has been proven that specific thought should be given to areas such as tools and methods; scientific and technical partnerships, alliances of a technological nature; funding; marketing of innovative products and services.

\section{What are the thoughts on public policy?}

For organizations governing public policies in research and development, grants or innovation backing, technological management also offers fields of thought and investigation which are complementary to those of companies:

- Management of the research - innovation process
Establishing policies based on the creation and/or reinforcement of poles of competencies obviously requires specific managerial skills: Management of research \& development; Management of the research-industry technology transfer; Project management; Management of research-industry interfaces; Management tools for public R\&D; Specific grants for SMEs.

- Scientific and technological scanning: Technological forecasting; Prospective and futurology.

- Scientific and technological politics: Technological assessment; Sustainable development and technical change; Science, technology and civil society; Methods and tools to encourage private R\&D; Management of innovation centers: local, regional, national, transnational, worldwide; Tools and process for localizing technologies.

Streams of thought on the necessary intervention of public policies, as catalysts of innovation capacities, quite obviously belong to the realms of technological management today. In such a context, the local, for want of saying territorial, dimension of the management of research and innovation becomes a major stream of reflection, since the main legitimate concern of politicians and authorities is to create and maintain jobs. However, management sciences should contribute to a better understanding of the key factors, not only of creativity, hence the genesis of innovations, but also and perhaps especially, of the capacity to adopt and adapt to such changes and therefore of the long-term survival of innovative organizations. Research has succeeded in developing models and tools, albeit they imperfect, for managing technology generation, but it has not elaborated tools and methods which cover the transition from $\mathrm{R} \& \mathrm{D}$ and innovation to industrial production, and therefore the long-term survival of innovative firms. In this respect, obviously, the local impact is a determining factor, especially in terms of job prospects.

\section{Lessons for education and training}

According to Hatchuel [11], mastering technological innovations requires multiple competencies ranging from fundamental research to design, style and marketing which, indeed, change at a rate that is proportionally opposite to technological intensity. The more an activity is technologically complex, the more value will be created by the innovation, the fewer competencies will be available off the shelf and ready to use, thus the more and the faster they will be transformed.

Hatchuel [13] adds that « often, when competition concerns innovation, companies, employees and public authorities are not confronted with simple skills management/acquisition, but with the permanent necessity to organize their creation and renewal». This means that the management of 
competition and economic growth depends on the appropriate management of individual and collective learning of the new skills required by innovation policies and strategies.

No doubt the education and training programs of managerial disciplines in technological management should be completely reformed, regardless of whether they address populations of engineers or managers. Indeed, the strategic management of technology and innovation should offer specific education modules and modules that are crossmatched with other functional disciplines (finance, marketing, accounting and cost control, human resources management, information systems management, etc.).

$$
\text { 4. CONCLUSION }
$$

It is indeed the «time-to-market» variable of innovations that is considered as crucial today. Corporations and nations have to innovate more often but also much faster. Two of the major issues of technological management are measuring the performance of organizations, of tools and procedures for managing the innovation process and anticipating the future evolutions of markets: technologies, actors, performances (prices and profits). It is indeed this second point for which companies are the least prepared. Most of them «play it by ear ». In daily business practice, management of technology and innovation seems like gambling on the future, a confession of faith, an «art » of management that is supposed to follow reasoning and use tools and recipes that have been proven by experience. But, in a context where technology is constantly pushing its way forward, proper strategic management of innovation cannot exist without a structured analytical and methodological corpus.

Finally, we can retain a definition that encompasses all of these dimensions: «technological management can be defined as a managerial approach based on optimizing the permeability and plasticity of the productive and entrepreneurial system with respect to technological dynamics. In reactive mode, it is structured around the flexible appropriation of technological evolutions. In proactive mode, it contributes to the emergence of alternative forms of technical progress»».

The strategic management of technology and innovation is evidently compelled to embrace the two « societal » paths of innovation: satisfying the needs or the demand for new products and services(demand pull), on the one hand, and the scientific and technical creation of new applications (technology push), on the other.

It is indeed a matter of contributing to the creation of a virtuous circle - - generation - acquisition - appropriation valorization of knowledge and technologies, new veins of growth and sustainable development, which perhaps contrast with the prevailing, albeit somewhat dated ideology of neo-liberal globalization and empowered markets while trying to ensure maximum well-being for individuals. The strategic management of technology and innovation should play an active part in elaborating new « business processes » for new products and services and will inevitably call for: 1 . new functioning rules; 2. renewed forms of organization; 3 . new managerial behaviors; and 4. new ways of measuring efficiency.

The added value of such a revisited vision of technology management is reflected into the «demand» by global corporations as well as SMEs for tools for diagnosis and operational management of innovation within a context which is perceived as highly threatening and uncertain.

\section{ACKNOWLEDGMENT}

The authors would like to thank their colleagues who contributed to suggest improvements to the initial versions of the paper.

\section{REFERENCES}

[1] Le Boucher, E., (2005), La France, son industrie, ses champions : critiques du rapport Beffa, Le Monde, 23-24 janvier.

[2] Khalil, T., (1998), Management of Technology: Future Directions and Needs for the New Century, A Report of the Workshop on Management of Technology, National Science Foundation, Arlington, September 14-15.

[3] Khalil, T., Bayraktar, B.A., (1990), Management of Technology, the Key to Global Competitiveness, Proceedings, $2^{\text {nd }}$ International Conference on Management of Technology, Miami, Feb. 28 - March 2.

[4] Barrand, J., Jolly, D., (1995), Le management irrigué par la technologie, Les Cahiers du Management Technologique, janvier/avril, $\mathrm{n}^{\circ} 13,9-18$.

[5] Chanaron J.J. Jolly D. (1999), Technological management: expanding the perspective of management of technology, Management Decision, 37, 8, 613-621.

[6] Chanaron J.J., Jolly D. et Soderquist K. (2002), Technological management : a tentative research agenda, International Journal of Technology Management, 23, 6, 618-629.

[7] Christensen, C.M., Corporate strategy and the management of innovation and technology, Industrial and Corporate Change, Vol, $11, \mathrm{n}^{\circ} 2,263-288$.

[8] Burgelman, R.A., Christensen, C.M., Wheelwright, S.C., (2004), Strategic Management of Technology and Innovation, McGraw Hill, Boston, Fourth Edition.

[9] Chanaron, J.J., (1998), Managing Innovation in European Small and Medium-Sized Enterprises, Nijmegen Lectures on Innovation Management, Nijmegen Business School, Maklu-Uitgevers, Antwerpen.

[10] Scabrough, H., Swan, J., (2001), Explaining the Diffusion of Knowledge Management: The Role of Fashion, British Journal of Management, Vol, 12, 3-12.

[11] Hatchuel, A., (2005), Towards an epistemology of collective action: management research as a responsive and actionable discipline, European Management Review, 2, pp. 36-47.

[12] Scott, G.M., (1999), Top priority management concerns about new product development, The Academy of Management Executive, August, 13;3, 77-84.

[13] Hatchuel, A., (2005), Compétences et innovation, Le Monde, 18 janvier.. 